\title{
Influence of Long Term Tillage, Organic and Inorganic Fertilization on Primary Nutrient and $S$ in Rice - Lentil Cropping Sequence under Dry Land Ecosystem
}

\author{
Shankar Ram ${ }^{\text {* }}$, A.K. Ghosh ${ }^{1}$, A.K. Nema ${ }^{2}$, Shishu Pal Singh ${ }^{1}$, \\ Vimal Kumar ${ }^{1}$ and Preeti Singh ${ }^{1}$
}

${ }^{1}$ Department of Soil Science and Agricultural Chemistry, Institute of Agricultural Sciences, Banaras Hindu University, Varanasi - 221 005, Uttar Pradesh, India

${ }^{2}$ Department of Farm Engineering, Institute of Agricultural Sciences, Banaras Hindu

University, Varanasi - 221 005, Uttar Pradesh, India

*Corresponding author

\begin{tabular}{|c|c|}
\hline & A B S T R A C T \\
\hline & \multirow{8}{*}{$\begin{array}{l}\text { Soil management practices may change the soil properties. The magnitude of the change } \\
\text { varies according to the soil property, the climate, and the type and time of implementation } \\
\text { of a particular management system. The aim of this study was to evaluate the effects of } \\
\text { tillage i.e. conventional tillage }\left(\mathrm{T}_{1}\right) \text {, reduced tillage }\left(\mathrm{T}_{2}\right) \text { and minimum tillage }\left(\mathrm{T}_{3}\right) \text { and } \\
\text { fertilization i.e. inorganic }\left(\mathrm{F}_{1}\right), 50 \% \text { organic }\left(\mathrm{F}_{2}\right) \text { and organic }\left(\mathrm{F}_{3}\right) \text { on the chemical } \\
\text { properties of an Inseptisol in the Indo-gangatic plain in dry land condition on available } \mathrm{N} \text {, } \\
\mathrm{P}, \mathrm{K} \text { and } \mathrm{S} \text { determined in a field experiment having a rice }(\text { Oryza sativm }) \text { lentil } \\
\text { (Lenseesculentum) crop rotation. Soil samples were collected after the nine and tenth year } \\
\text { of experimentation and were analyzed for, chemical parameters. The change in soil } \\
\text { chemical properties was evaluated using soil samples after rice and lentil at } 0-5 \text { and } 10-15 \\
\text { cm depth. The results showed that soil available macro nutrients like } \mathrm{N}, \mathrm{P}, \mathrm{K} \text { and } \mathrm{S} \text { were } \\
\text { higher in surface soil }(0-5 \mathrm{~cm}) \text { as compared to sub surface soil }(10-15 \mathrm{~cm}) \text { after rice and } \\
\text { also after lentil crop the value was higher after rice than after lentil crop. }\end{array}$} \\
\hline Keywords & \\
\hline & \\
\hline & \\
\hline Article Info & \\
\hline & \\
\hline & \\
\hline & \\
\hline
\end{tabular}

\section{Introduction}

Dryland agriculture refers to cultivation of crops entirely under natural rainfall. It is a form of subsistence farming in the regions where deficit of the soil moisture retards the growth of water consuming crops like paddy (Oryza sativa), sugarcane (Saccharum officinarum) etc. Dryland areas are characterized by low and erratic rainfall and no assured irrigation facilities. Dryland agriculture is important for the economy as most of the coarse grain crops, pulses, oilseeds, and raw cotton are grown on these lands. Dryland areas receive rainfall between 50 and $120 \mathrm{~cm}$. Tillage systems, farm manures and chemical fertilizers had variable effects on rice yield and growth. The farm manure improves the organic carbon by application of farm manure (Khan et al., 2010). The soil properties must be favourable to crop growth. Organic carbon performs additional functions 
of increasing soil organic matter content, and CEC, enhance biological activity, improve soil structure (Uwah and Iwo, 2011). Manure is excellent fertilizer containing most of the major and micro nutrients. It also adds organic matters to the soil which improves soil health. A higher input of biomass $\mathrm{C}$ through the application of organic amendments or combined use of organics and chemical fertilizers may be due to increased availability of essential nutrients (i.e., N, P, K, Ca, Mg, S, Zn and B) (Srinivasarao and Vittal, 2007).

Organic matter promotes microorganism those are beneficial to plant growth because they fix certain nutrients, which lasts in soil until consumed by the plants. The principle value of manure is it's extended available of nitrogen of particular value in the more readily leached sandy soils. Manure is also helpful in improving soil fertility in eroded areas from land levelling. Different fertilization treatments of a long-term field experiment can cause soil macronutrients and their available concentrations to change, which in turn affects soil micronutrient levels. For example, excessive application of $\mathrm{P}$ inhibited the transfer of soil $\mathrm{Zn}$ and resulted in shortage of $\mathrm{Zn}$ in maize, due to possible precipitation of $\mathrm{Zn}_{3}\left(\mathrm{PO}_{4}\right)_{2}$. Soil OM exerts a significant and direct impact on the availability of $\mathrm{Zn}, \mathrm{Fe}$ and Mn but has little influence on the availability of soil $\mathrm{Cu}$ (Zhang et al., 2001). The availability of micronutrients in the soil can strongly affect the production and quality of crops. As a result of the change of basic soil characteristics, such as nutrients in response to long-term fertilization field experiments, status and behaviours of micronutrients in soil and crop vary with different fertilization practices. For instance, available $\mathrm{Zn}$ and $\mathrm{Cu}$ levels in cropped treatments were lower than the fallow treatment, probably due to the removal of these micronutrients from soil through crop uptake and harvest. In contrast, available $\mathrm{Mn}$ and Fe levels were higher in cropped treatments compared to the fallow treatment (Wei et al., 2006). Soil OMexerts a significant and direct impact on the availability of $\mathrm{Zn}, \mathrm{Fe}$ and $\mathrm{Mn}$ but has little influence on the availability of soil $\mathrm{Cu}$ (Zhang et al., 2001). In addition, the interaction of other soil macronutrients and micronutrients also affected micronutrients uptake by crops (Aulakh and Malhi, 2005).

\section{Materials and Methods}

\section{Experimental site}

The study was conducted in a long-term experimental field established at Agricultural Research Farm, Institute of Agricultural Sciences, B.H.U Varanasi in rice(cv ND-97)lentil (cv Malyiya Vishwanath) cropping sequence to test the possible effects of tillage and incorporating fertilizer on soil fertility. Institute of Agriculture Sciences, B.H.U is situated under the greater periphery of the Holy city Varanasi at $82.52{ }^{0} \mathrm{E}$ longitude and 25.10 " N latitude and $76.19 \mathrm{~m}$ above mean sea level. The Varanasi district of Uttar Pradesh lies between the parallels of $24^{0} 43$ and $25^{\circ} 35^{\text {, }}$ latitude and $82^{0} 11$ ' E longitude covering a geographical area of about $1578 \mathrm{~km}^{2}$. Varanasi lies in the middle of the IndoGangetic plain and falls under the agro ecological zone (AEZ). This AEZ has an area of 12.1 million hectares $(3.7 \%$ of the total geographical area of India) and covers 11.62 million hectares of total gross cropped area. The experimental soil is an Inceptisol with sandy loam texture.

\section{Treatments}

The experimental design was a split-plot with three main treatments, three sub treatments and three replications. The three maintreatments were: conventional tillage (T1), reduced tillage (T2) and minimum tillage (T3) and Sub-treatments included fertilization i.e. inorganic or RDF (F1), 50\% organic (F2) and organic (F3). The conventional tillage 
constituted of two passes of disk followed by one pass of cultivator. The reduced tillage constituted of one pass of disk and one pass of cultivator whereas the minimum tillage constituted of one pass of cultivator. Treatments are applied to rice and followed up in lentil (except one common minimum tillage given for sowing lentil).

The experiment stand by conventional tillage for field preparation and layout of permanent plot under split plot design. Rice was planted during the kharif of each year and harvested by the end of October. During rabi season, lentil was planted and standard agronomic practices were followed for cultivation. Paddy seeds were sown directly in lines $30 \mathrm{~cm}$ apart after field preparation usually in the 13 July 2012. Lentil was sown $30 \mathrm{~cm}$ apart after a common tillage given after rice harvest usually in the month of October because of the monsoon rains.

The experiment comprises of 3 fertilizer treatments. Fertilizer treatments consisted of recommended dose of fertilizer (RDF) (N$\mathrm{P}_{2} \mathrm{O}_{5}-\mathrm{K}_{2} \mathrm{O} @ 80: 40: 30 \mathrm{~kg} \mathrm{ha}^{-1}$ ) for rice and RDF (N-P $\mathrm{O}_{5}-\mathrm{K}_{2} \mathrm{O} @ 20: 40: 20 \mathrm{~kg} \mathrm{ha}^{-1}$ ) for lentil. Organic manures in the form of FYM was integrated with inorganic fertilizers. The basic idea was to reduce the dependence on chemical fertilizers and supplement them with locally available organic resource.

The whole amount of $\mathrm{P}$ and $\mathrm{K}$ was applied as basal dressing through diammonium phosphate (DAP) and muriate of potash (MOP), while nitrogen was applied in three splits viz. $40 \mathrm{~kg} \mathrm{~N} \mathrm{ha}^{-1}$ as basal and remaining $40 \mathrm{~kg} \mathrm{~N}$ in two equal splits at active tillering and panicle initiation stage. A uniform basal application of phosphorus and potassium was made through diammonium phosphate (DAP) and muriate of potash (MOP), respectively to all the plots. In case of lentil, RDF was applied in each plot for initial growth of plant.

\section{Sample analysis}

Soil samples were air-dried and ground to pass through a $2 \mathrm{~mm}$ sieve for the analysis of soil. Available nitrogen content of soil was determined by alkaline permanganate method (Subbia and Asija, 1956).Available phosphorus (Olsen's method) by extraction with $\mathrm{NaHCO}_{3} \quad 0.5 \mathrm{~mol} \mathrm{~L} \mathrm{~L}^{-1}$ at $\mathrm{pH} 8.5$ and colorimetric determination. Available potassium by extraction with ammonium acetate $1 \mathrm{~N} \mathrm{~L}^{-1}$ at $\mathrm{pH} 7$ and determination by flame photometer (Hanway and Heidal, 1952). Available sulphur content was determined by Turbidi metrically (Chesnin and Yien, 1951).

\section{Data statistical analysis}

The data obtained were analyzed for Analysis of Variance (ANOVA) using excel and means separated using critical difference and presented in tables.

\section{Results and Discussion}

\section{Effects of long-term tillage and fertilization treatments on soil nutrient status}

\section{Available nitrogen}

There was significant influence of tillage on available nitrogen content after rice at both 0 5 and 10-15 cm depth even after 10 cropping cycles (Table 1 and Fig. 1). The average nitrogen content was $250.85 \mathrm{~kg} \mathrm{ha}^{-1}$ in plots under conventional tillage. However with reduction in tillage, the average $\mathrm{N}$ content increased significantly to $270.39 \mathrm{Kg} \mathrm{ha}^{-1}$. Plots under minimum tillage however had lower available N content after rice. Similar results have been obtained by other workers. Khan et al., (2010) working on the influence of tillage and farm yard manure reported higher $\mathrm{N}$ content under minimum tillage and lower $\mathrm{N}$ content under conventional tillage. Franzluebbers et al., (1999) reported that SOC 
and TN content decreased with increase in the intensity and frequency of tillage operations. The available nitrogen content at $10-15 \mathrm{~cm}$ soil depth followed a similar pattern but the available $\mathrm{N}$ contents were considerably lower. Among the fertilization treatments there was no significant difference between the inorganic and $100 \%$ organic treatments in the $0-5 \mathrm{~cm}$ soil layer. However $50 \%$ organic treatment was considerable inferior to either inorganic or $100 \%$ organic treatment for as the available $\mathrm{N}$ content is consumed. But at 10-15 $\mathrm{cm}$ depth, the available $\mathrm{N}$ content was considerably more in the $100 \%$ organic treatment as compared to inorganic or $50 \%$ organic treatment after rice.

Jamwal (2006) reported that the available $\mathrm{N}$ status of the soil after maize harvest was significantly affected by fertility levels. The highest amount of available $\mathrm{N}$ was observed under 10 tonnes FYM/ha, followed by half the recommended $\mathrm{N}+$ half $\mathrm{N}$ through FYM, recommended NPK + $20 \mathrm{~kg} \mathrm{ZnSO}_{4} /$ ha and recommended NPK levels. There was also effect of fertilization on available nitrogen content after rice at both the soil depth i.e. 0-5 and $10-15 \mathrm{~cm}$. This is probably because plots received nitrogen on equivalent basis and organic nitrogen quickly mineralized to inorganic nitrogen which might have maintained similar soil nitrogen levels. Interaction effect of tillage and nitrogen was also significant.

There was no significant influence of tillage on available nitrogen content after lentil at both $0-5$ and $10-15 \mathrm{~cm}$ depth even 10 cropping cycles (Table 2 and Fig. 2). However there was significant effect of fertilization on available nitrogen content after lentil at 0-5 $\mathrm{cm}$ soil depth. There was no effect of fertilization on available nitrogen content after lentil at $10-15 \mathrm{~cm}$ soil depth. Interaction effect of tillage and nitrogen was significant at soil depth 0-5 cm but not at $10-15 \mathrm{~cm}$ soil depth.

\section{Available phosphorus}

There was no significant influence of tillage on available phosphorus content after rice at 0-5 cm depth, whereas significant influence of tillage on available phosphorus content after rice at $10-15 \mathrm{~cm}$ depth was observed (Table 1 and Fig. 1). There was significant effect of fertilization on available phosphorus content after rice at soil depth is $0-5 \mathrm{~cm}$. In general the available $\mathrm{P}$ content in the $0-5 \mathrm{~cm}$ layer was more than $10-15 \mathrm{~cm}$ layer indicating accumulation of $P$ in the surface soil $(0-5 \mathrm{~cm})$. The increase in available $P$ content with increase in organic manure application at both the soil depths is probably because all plots received $P$ fertilization @ Rice + Lentil (40 kg $\left.\mathrm{ha}^{-1}\right)$. Considering the average $\mathrm{P}$ content of FYM to be $0.25 \% \quad \mathrm{P}_{2} \mathrm{O}_{5}$, each year an additional amount of 20 and $40 \mathrm{Kg} \mathrm{P}$ was being added in plots receiving 50\% and $100 \%$ organic manures respectively. This probably resulted in build-up of available $\mathrm{P}$ in plots receiving organic manure. Which this build-up was of to the tune of $22 \%$ for the $100 \%$ organic treatment in 0-5 cm layer, it increased to $76 \%$ in the $10-15 \mathrm{~cm}$ soil layer after rice. Although tillage system did not show any significant differences in the available $P$ content in $0-5 \mathrm{~cm}$ after rice, the effect was significant at $10-15 \mathrm{~cm}$ depth. Higher values of available $\mathrm{P}$ was observed with decreasing tillage intensity. This is probably because with increasing tillage, more and more $\mathrm{P}$ comes into contact with soil constituents and get fixed. It has been reported that in acid soils, $\mathrm{P}$ is fixed into slightly soluble form by precipitation and sorption reaction with $\mathrm{Fe}$ and Al compounds as well as crystalline and amorphous solids. In calcareous soils surface adsorption and precipitation are the major $\mathrm{P}$ retention processes depressing $\mathrm{P}$ availability and mobility (Pizzeghella et al., 2011). Manure affected $\mathrm{P}$ availability positively by reducing $\mathrm{P}$ adsorption through competition for fixation sites by organic acids, favouring the 
formation of metal-humates-phosphates complex and decreasing the rate of precipitation of non-soluble calcium phosphates (Pizzeghella et al., 2014). Robbins and Voss (1991) found a higher amount of available $\mathrm{P}$ in the top $5 \mathrm{~cm}$ depth in a silt loam soil managed under NT as compared to ridge tillage. Ismail et al., (1994) found greater extractable $\mathrm{P}$ in the top $5 \mathrm{~cm}$ of a silt loam soil after 20 years under NT management. From 5 to $30 \mathrm{~cm}$ depth extractable $\mathrm{P}$ was lower under NT than under CT. The effect of NT management in the available $\mathrm{P}$ distribution, at deeper depths, was reported by Thomas et al., (2007). In their study, available P was higher in the top $10 \mathrm{~cm}$ depth of a Typic Natrustalf managed under NT as compared to a mouldboard ploughed soil. Martin-Rueda et al., (2007) reported that extractable $\mathrm{P}$ was higher for no tillage in the surface layer (0-15 $\mathrm{cm}$ ) in comparison with minimum tillage, which was greater than conventional tillage. At $15-30 \mathrm{~cm}$, no tillage and minimum tillage had higher $\mathrm{P}$ than conventional tillage. In deeper soil layers, significant differences in $\mathrm{P}$ were not found for the different tillage systems. Interaction effect of tillage and phosphorus was also significant at both soil depth $0-5$ and $10-15 \mathrm{~cm}$.

There was no significant influence of tillage on available phosphorus content after lentil at $0-5 \mathrm{~cm}$ depth even after 10 cropping cycles (Table 2 and Fig. 2). There was also no effect of fertilization on available phosphorus content after lentil at soil depth is $0-5 \mathrm{~cm}$. But there was significant influence of tillage on available phosphorus content after lentil at 10$15 \mathrm{~cm}$ depth. There was also significant effect of fertilization on available phosphorus content after lentil at soil depth 10-15 cm. Interaction effect of tillage and phosphorus was no significant at both soil depth $0-5$ and $10-15 \mathrm{~cm}$.

\section{Available potassium}

Tillage, fertilization and their interaction, positively influenced the available potassium content in the $0-5$ and $10-15 \mathrm{~cm}$ depth after rice (Table 1 and Fig. 1). The highest available $\mathrm{K}$ content was observed in reduced tillage treatment and the lowest in conventional tillage at both soil depths. However the available $\mathrm{K}$ content in the $10-15 \mathrm{~cm}$ soil depth was considerably lower than the $0-5 \mathrm{~cm}$ soil depth. Similar trend was obtained by MartinRueda et al., (2007) that extractable K was higher for no tillage in the surface layer (0-15 $\mathrm{cm})$ in comparison with minimum tillage, which was greater than conventional tillage. At $15-30 \mathrm{~cm}$, no tillage and minimum tillage had higher $\mathrm{K}$ than conventional tillage. In deeper soil layers significant differences in $\mathrm{K}$ was not found for the different tillage systems. Treatments that obtained organic manuring always recorded higher available $\mathrm{K}$ content than $100 \%$ inorganic treatment. This is because, FYM contained $0.5 \% \mathrm{~K}_{2} \mathrm{O}$ on dry weight basis and an additional amount of 20 and $40 \mathrm{~kg} \mathrm{~K}_{2} \mathrm{O}$ was added each year in the plots receiving $50 \%$ and $100 \%$ organic manures respectively. The available $\mathrm{K}$ content after lentil was however not significantly influence by either tillage or fertilization at both the soil depths i.e. 0-5 and 10-15 cm layer (Table 2 and Fig. 2). This is probably because $\mathrm{K}$ potassium was taken up by in lentil crop and the effect after rice their levelled off. Carter et al., (2002) noted non-significant differences among the treatments. The effect of farm yard manure on potassium concentration (ppm) was recorded significantly. Higher potassium concentration (189.4 ppm) was observed with application of FYM @ $40 \mathrm{Mg} \mathrm{ha}^{-1}$ against the least (157.9 ppm) potassium concentration in application of recommended NPK. 
Table.1 Influence of tillage and fertilization on available nutrient in soil at 0-5 and 10-15 cm depth after rice

\begin{tabular}{|c|c|c|c|c|c|}
\hline \multicolumn{6}{|c|}{$0-5 \mathrm{~cm}$} \\
\hline Tillage & Fertilization & $\mathrm{N}\left(\mathrm{kg} \mathrm{ha}^{-1}\right)$ & $\mathrm{P}\left(\mathrm{kg} \mathrm{ha}^{-1}\right)$ & $\mathrm{K}\left(\mathrm{kg} \mathrm{ha}^{-1}\right)$ & $\mathrm{S}\left(\mathrm{mg} \mathrm{Kg}^{-1}\right)$ \\
\hline \multirow[t]{3}{*}{$\mathrm{CT}$} & $F_{1}$ & 238.34 & 92.60 & 189.28 & 3.78 \\
\hline & $\mathrm{F}_{2}$ & 250.88 & 102.3 & 185.57 & 6.56 \\
\hline & $\mathrm{F}_{3}$ & 263.42 & 117.4 & 177.87 & 7.95 \\
\hline \multirow[t]{3}{*}{ RT } & $F_{1}$ & 284.33 & 96.19 & 172.80 & 3.86 \\
\hline & $\mathrm{F}_{2}$ & 250.88 & 108.9 & 222.30 & 4.25 \\
\hline & $\mathrm{F}_{3}$ & 275.97 & 124.1 & 238.10 & 6.56 \\
\hline \multirow[t]{3}{*}{$\overline{M T}$} & $\mathrm{~F}_{1}$ & 275.97 & 96.86 & 173.23 & 5.80 \\
\hline & $\mathrm{F}_{2}$ & 188.16 & 111.6 & 197.07 & 8.42 \\
\hline & $\mathrm{F}_{3}$ & 238.34 & 122.4 & 188.00 & 10.8 \\
\hline \multirow{3}{*}{\multicolumn{2}{|c|}{$\begin{array}{c}\mathbf{T} \\
\mathbf{F} \\
\mathbf{T} \times \mathbf{F}\end{array}$}} & $*$ & NS & $*$ & $*$ \\
\hline & & $*$ & $*$ & $*$ & $*$ \\
\hline & & * & NS & * & * \\
\hline \multicolumn{6}{|c|}{$10-15 \mathrm{~cm}$} \\
\hline Tillage & Fertilization & $\mathrm{N}\left(\mathrm{kg} \mathrm{ha}^{-1}\right)$ & $\mathrm{P}\left(\mathrm{kg} \mathrm{ha}^{-1}\right)$ & $\mathrm{K}\left(\mathrm{kg} \mathrm{ha}^{-1}\right)$ & $\mathrm{S}\left(\mathrm{mg} \mathrm{Kg}^{-1}\right)$ \\
\hline \multirow[t]{3}{*}{ CT } & $F_{1}$ & 175.62 & 24.22 & 98.26 & 3.86 \\
\hline & $\mathrm{F}_{2}$ & 188.16 & 28.59 & 161.65 & 5.69 \\
\hline & $\mathrm{F}_{3}$ & 183.98 & 58.19 & 161.02 & 5.69 \\
\hline \multirow[t]{3}{*}{$\begin{array}{l}\text { RT } \\
\text { R }\end{array}$} & $\mathrm{F}_{1}$ & 171.44 & 35.99 & 159.19 & 4.68 \\
\hline & $\mathrm{F}_{2}$ & 200.70 & 48.77 & 172.26 & 5.29 \\
\hline & $\mathrm{F}_{3}$ & 163.07 & 57.85 & 219.22 & 6.30 \\
\hline \multirow[t]{3}{*}{ MT } & $\mathrm{F}_{1}$ & 175.62 & 48.43 & 151.54 & 5.69 \\
\hline & $\mathrm{F}_{2}$ & 179.80 & 52.80 & 175.28 & 5.69 \\
\hline & $\mathrm{F}_{3}$ & 183.98 & 68.28 & 137.05 & 6.10 \\
\hline \multirow{3}{*}{\multicolumn{2}{|c|}{$\begin{array}{c}\mathbf{T} \\
\mathbf{F} \\
\mathbf{T} \times \mathbf{F}\end{array}$}} & NS & $*$ & * & NS \\
\hline & & $*$ & * & * & $*$ \\
\hline & & $*$ & * & * & NS \\
\hline
\end{tabular}

*Significance at $\mathrm{CD}_{5 \%}$

$\mathrm{CT}=$ Conventional tillage, $\mathrm{RT}=$ Reduced Tillage and $\mathrm{MT}=$ Minimum tillage

$\mathrm{F}_{1}=$ Inorganic, $\mathrm{F}_{2}=50 \%$ Organic and $\mathrm{F}_{3}=$ Organic 
Table.2 Influence of tillage and fertilization on available nutrient in soil at $0-5$ and $10-15 \mathrm{~cm}$ depth after lentil

\begin{tabular}{|c|c|c|c|c|c|}
\hline \multicolumn{6}{|c|}{$0-5 \mathrm{~cm}$} \\
\hline Tillage & Fertilization & $\mathrm{N}\left(\mathrm{kg} \mathrm{ha}^{-1}\right)$ & $\mathrm{P}\left(\mathrm{kg} \mathrm{ha}^{-1}\right)$ & $\mathrm{K}\left(\mathrm{kg} \mathrm{ha}^{-1}\right)$ & $\mathrm{S}\left(\mathrm{mg} \mathrm{Kg}^{-1}\right)$ \\
\hline \multirow[t]{3}{*}{$\mathrm{CT}$} & $\mathrm{F}_{1}$ & 175.62 & 65.25 & 125.1 & 4.68 \\
\hline & $\mathrm{F}_{2}$ & 188.16 & 79.10 & 114.4 & 7.22 \\
\hline & $\mathrm{F}_{3}$ & 183.98 & 84.76 & 130.9 & 7.73 \\
\hline \multirow[t]{3}{*}{$\mathbf{R T}$} & $\mathrm{F}_{1}$ & 171.44 & 67.69 & 107.3 & 5.69 \\
\hline & $\mathrm{F}_{2}$ & 200.70 & 88.79 & 122.3 & 8.13 \\
\hline & $\mathrm{F}_{3}$ & 163.07 & 94.94 & 127.0 & 10.4 \\
\hline \multirow[t]{3}{*}{ MT } & $\mathrm{F}_{1}$ & 175.62 & 70.63 & 125.0 & 6.51 \\
\hline & $\mathrm{F}_{2}$ & 179.80 & 86.77 & 114.4 & 8.34 \\
\hline & $\mathrm{F}_{3}$ & 183.98 & 103.9 & 130.9 & 11.6 \\
\hline \multirow{3}{*}{\multicolumn{2}{|c|}{$\begin{array}{c}\mathbf{T} \\
\mathbf{F} \\
\mathrm{T} \times \mathbf{F}\end{array}$}} & NS & NS & $*$ & NS \\
\hline & & $*$ & $*$ & $*$ & NS \\
\hline & & $*$ & NS & $*$ & $*$ \\
\hline \multicolumn{6}{|c|}{$10-15 \mathrm{~cm}$} \\
\hline Tillage & Fertilization & $\mathrm{N}\left(\mathrm{kg} \mathrm{ha}^{-1}\right)$ & $\mathrm{P}\left(\mathrm{kg} \mathrm{ha}^{-1}\right)$ & $\mathrm{K}\left(\mathrm{kg} \mathrm{ha}^{-1}\right)$ & $\mathrm{S}\left(\mathrm{mg} \mathrm{Kg}^{-1}\right)$ \\
\hline \multirow[t]{3}{*}{ CT } & $\mathrm{F}_{1}$ & 125.44 & 19.17 & 101.8 & 3.24 \\
\hline & $\mathrm{F}_{2}$ & 133.80 & 28.28 & 99.13 & 4.40 \\
\hline & $\mathrm{F}_{3}$ & 137.98 & 35.65 & 102.3 & 5.09 \\
\hline \multirow[t]{3}{*}{$\mathbf{R T}$} & $\mathrm{F}_{1}$ & 129.62 & 23.15 & 99.68 & 3.94 \\
\hline & $\mathrm{F}_{2}$ & 125.44 & 45.83 & 94.45 & 5.09 \\
\hline & $\mathrm{F}_{3}$ & 121.26 & 50.29 & 91.98 & 5.33 \\
\hline \multirow[t]{3}{*}{ MT } & $\mathrm{F}_{1}$ & 146.35 & 45.10 & 114.5 & 3.94 \\
\hline & $\mathrm{F}_{2}$ & 154.71 & 49.68 & 97.2 & 5.33 \\
\hline & $\mathrm{F}_{3}$ & 133.80 & 65.73 & 107.9 & 6.02 \\
\hline \multirow{3}{*}{\multicolumn{2}{|c|}{$\begin{array}{c}\mathrm{T} \\
\mathrm{F} \\
\mathrm{T} \times \mathrm{F}\end{array}$}} & NS & $*$ & $*$ & NS \\
\hline & & NS & $*$ & $*$ & NS \\
\hline & & NS & $*$ & $*$ & $*$ \\
\hline
\end{tabular}

*Significance at $\mathrm{CD}_{5 \%}$

$\mathrm{CT}=$ Conventional tillage, $\mathrm{RT}=$ Reduced Tillage and $\mathrm{MT}=$ Minimum tillage

$\mathrm{F}_{1}=$ Inorganic, $\mathrm{F}_{2}=50 \%$ Organic and $\mathrm{F}_{3}=$ Organic 
Fig.1 Influence of tillage and fertilization on available nutrient in soil at 0-5 and 10-15 $\mathrm{cm}$ depth after rice
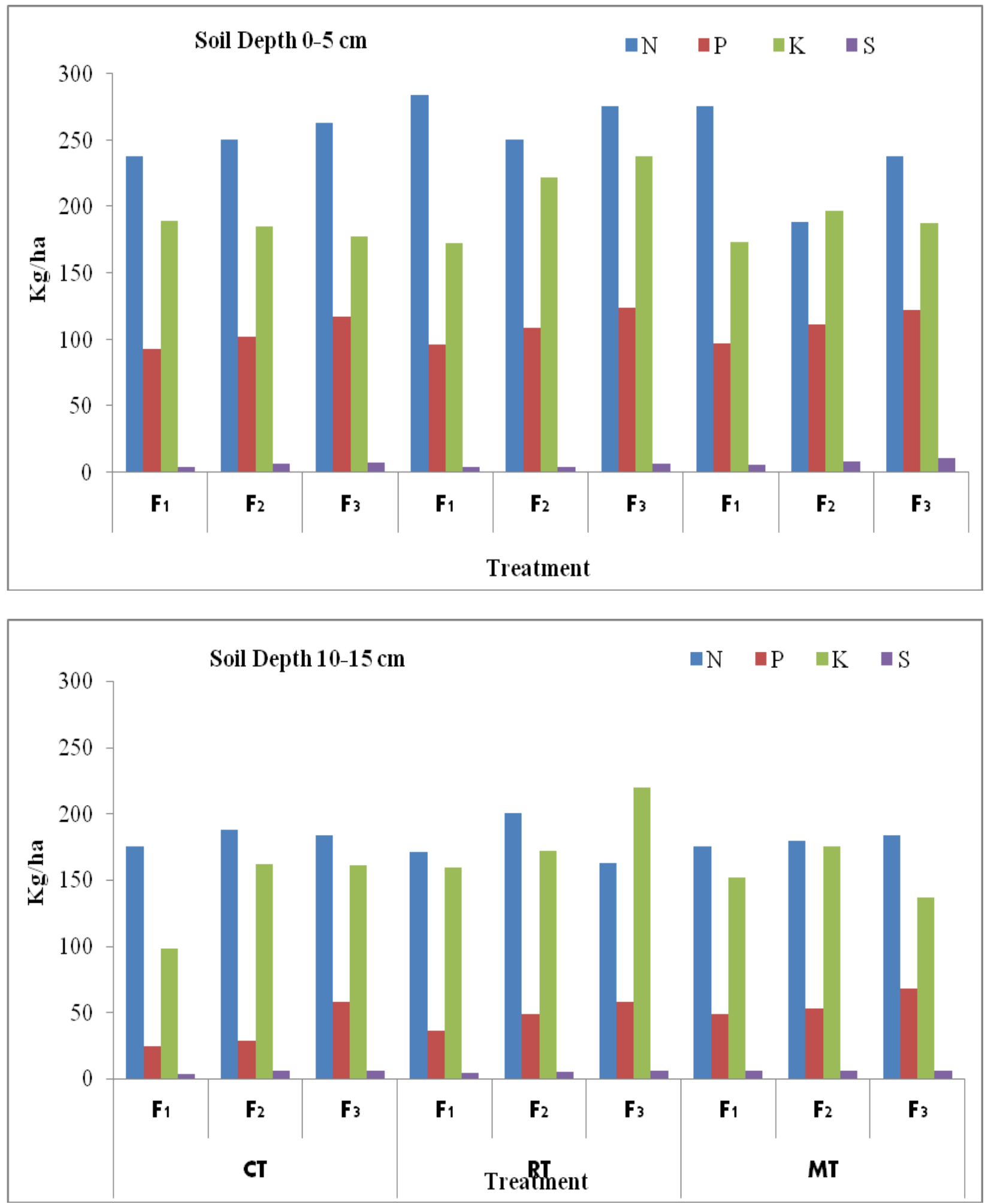

$\mathrm{CT}=$ Conventional tillage, $\mathrm{RT}=$ Reduced Tillage and MT $=$ Minimum tillage $\mathrm{F}_{1}=$ Inorganic, $\mathrm{F}_{2}=50 \%$ Organic and $\mathrm{F}_{3}=$ Organic 
Fig.2 Influence of tillage and fertilization on available nutrient in soil at $0-5$ and $10-15 \mathrm{~cm}$ depth after lentil
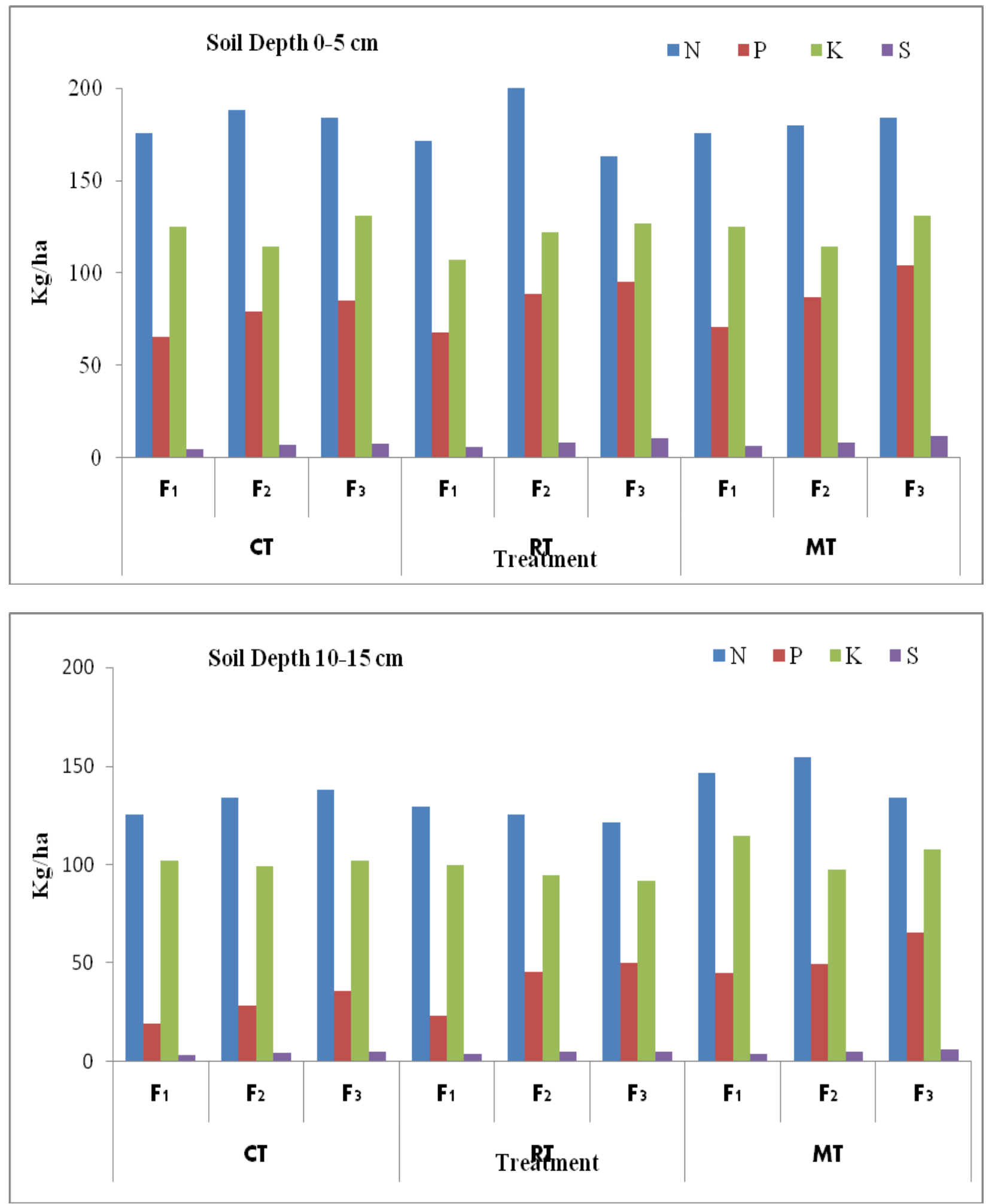

$\mathrm{CT}=$ Conventional tillage, $\mathrm{RT}=$ Reduced Tillage and $\mathrm{MT}=$ Minimum tillage $\mathrm{F}_{1}=$ Inorganic, $\mathrm{F}_{2}=50 \%$ Organic and $\mathrm{F}_{3}=$ Organic 
Mean increase in potassium contents was observed $19.9 \%$ and $11.3 \%$ in case of FYM @ $40 \mathrm{Mg} \mathrm{ha}^{-1}$ and $20 \mathrm{Mg} \mathrm{ha}^{-1}$, respectively as compare to recommended NPK.

\section{Available sulphur}

The available sulphur content was significantly influenced by tillage and fertilization in the $0-5 \mathrm{~cm}$ and by fertilization alone in the $10-15 \mathrm{~cm}$ depth after rice (Table 1 and Fig. 1). Except the plot under minimum tillage and $100 \%$ organic fertilization, all plots had available sulphur content below the critical limit of $10 \mathrm{ppm}$ sulphate $\mathrm{S}$. The available $S$ content increased from $4.48 \mathrm{mg}$ $\mathrm{kg}^{-1}$ in $100 \%$ inorganic fertilization to 8.44 in $100 \%$ organic manuring.

This is probably because FYM contained 0.06 $\% \mathrm{~S}$ on dry weight basis and 4.8 and $2.4 \mathrm{~kg}$ was added through FYM each year in plots receiving $50 \%$ and $100 \%$ organic manuring through FYM respectively. The effect of adding organic manures on the available $\mathrm{S}$ content was also evident in the $10-15 \mathrm{~cm}$ depth where a similar trend was obtained as $0-5 \mathrm{~cm}$ depth.

Sarkar et al., (1998) reported various organic sources like compost, FYM, green manure and crop residues can supply adequate quantity of sulphur to crops. Sharma et al., (2001) reported that integrated use of inorganic fertilizers and organic manures through FYM, crop residues of wheat and green manuring of dhaincha improve sulphur status of soil significantly over control.

The available $\mathrm{S}$ content was also significantly influenced in the 0-5 and 10-15 cm layer after harvest of lentil (Table 2 and Fig. 2). Reduced and minimum tillage treatments had significantly higher $S$ content in the $0-5$ and $10-15 \mathrm{~cm}$ depths. The available $\mathrm{S}$ content also increased with increase in the amount of manure addition and was higher in $100 \%$ organic plots fallowed by $50 \%$ organic plots and least in inorganic plots in both $0-5$ and $10-15 \mathrm{~cm}$ soil layer. Swarup and Ghosh (1980) studied the change in water soluble sulphur status as a result of manuring. They observed an increase in sulphur content of the soil with manuring but the maximum increase was with the application of FYM.

The long-term experiment demonstrated on the Indo-gangatic Plain in Dryland Farmthe effects of tillage i.e. conventional tillage $\left(T_{1}\right)$, reduced tillage $\left(T_{2}\right)$ and minimum tillage $\left(T_{3}\right)$ and fertilization i.e. inorganic $\left(\mathrm{F}_{1}\right), 50 \%$ organic $\left(\mathrm{F}_{2}\right)$ and organic $\left(\mathrm{F}_{3}\right)$ on available $\mathrm{N}$, $\mathrm{P}, \mathrm{K}$ and $\mathrm{S}$ determined in a field experiment having a rice (Oryza sativm) - lentil (Lenseesculentum) crop rotation.

There was significant influence of tillage, fertilization and their interaction on available $\mathrm{N}, \mathrm{P}$ and $\mathrm{S}$ content. There was significant influence of tillage and fertilization on available potassium content after rice or lentil. Reduced tillage with $100 \%$ inorganic and organic can increase available macro nutrient like $\mathrm{N}, \mathrm{P}, \mathrm{K}$ and $\mathrm{S}$ as compared to conventional tillage with $100 \%$ inorganic and organic, whereas minimum tillage with $100 \%$ inorganic can increase available $\mathrm{N}$ because of less volatilization loss of nitrogen and minimum tillage with $100 \%$ organic can increase available $\mathrm{P}, \mathrm{K}$ and $\mathrm{S}$. Whereas $50 \%$ organic has average effect on soil macro nutrient $0-5$ and $10-15 \mathrm{~cm}$ depth after rice.

Reduced tillage with $50 \%$ inorganic and organic can increase available macro nutrient like $\mathrm{N}$, as compared to conventional tillage, minimum tillage with $100 \%$ inorganic has almost same effect and minimum tillage with $100 \%$ organic can increase available P, K and S. Whereas $50 \%$ organic has average effect on soil macro nutrient $0-5$ and $10-15 \mathrm{~cm}$ depth after lentil. 


\section{References}

Aulakh, M.S., Malhi, S.S., 2005. Interactions of nitrogen with other nutrients and water: Effect on crop yield and quality, nutrient use efficiency, carbon sequestration, and environmental pollution. Adv. Agron. 86, 342-409.

Carter, M. R., Saderson, J. B., Ivany, J. A. and White, R. P. (2002) Influence of rotation and tillage on forage maize productivity, weed species and soil of a fine sandy loam in the humid climate of Atlantic, Canada. Soil and Tillage Research 67, 85-98.

Chesnin, L. and Yein, C. H. (1950) Turbidimetric determination of available sulphur. Soil Science Society of American Proceedings 15, 149-151.

Franzluebbers, A. J., Langdale, G. W. and Schomberg, H. H., (1999) Soil carbon, nitrogen, and aggregation in response to type and frequency of tillage. Soil Science Society of America Journal 63, 349-355.

Ismail, I., Blevins, R.L., Frye, W.W., (1994) Long-term no-tillage effects on soil properties and continuous corn yields. Soil Science Society of America Journal 58, 193-198.

Jamwal, J. S. (2006) Effect of integrated nutrient management in maize (Zea mays L) on succeeding winter crops under rain fed conditions. Indian Agronomy 51, 14-16.

Khan, N. I., Malik, A. U., Umer, F., and Bodla, M. I. (2010) Effect of tillage and farm yard manure on physical properties of soil International Research Journal of Plant Science 1, 75-82,

Li, B.Y., Zhou, D. M., Cang, L., Zhang, H. L., Fan, X. H. and Qin, S. W. (2007) Soil micronutrient availability to crops as affected by long-term inorganic and organic fertilizer applications. Soil and Tillage Research 96, 166-173
Martin-Rueda, I., Muñoz-Guerra, L. M., Yunta, F., Esteban, E., Tenorio, J. L. and Lucena, J. J. (2007) Tillage and crop rotation effects on barley yield and soil nutrients on a Calciortidic Haploxeralf. Soil and Tillage Research 92, 1-9.

Olsen, S. R., Cole, C. V., Watanable, F. S. and Dean, L. A. (1954) Estimation of available phosphorus in soils by extraction with sodium bicarbonate. USDA Circular 939.

Pizzeghella, D., Berti, A., Nardi, S. and Morari, F. (2011) Phosphorus forms and P-sorption properties in three alkaline soils after long-term mineral and manure applications in north-eastern Italy. Agriculture, Ecosystems and Environment 141, 58-66.

Robbins, S. G. and Voss, R. D. (1991) Phosphorous and potassium stratification in conservation tillage systems. Journal of Soil and Water Conservation 46, 298-300.

Robbins, S. G., and Voss, R. D. (1991) Phosphorous and potassium stratification in conservation tillage systems. Journal of Soil and Water Conservation 46, 298-300.

Sarkar, M. C., Sachdev, M. S., and Datta, S. P. (1998) Interaction of soil organic matter with nutrients. Bull. Indian Soc. Soil Sci. 19, 90-102.

Sharma, M. P., Bali, S. V. and Gupta, D. K. (2001) Soil fertility and productivity of rice (Oryza sativa) - wheat (Triticum aestivum) cropping system in an Inceptisol as influenced by integrated management. Indian J. Agric. Sci. 71, 82-86.

Srinivasarao, C. and Vittal, K. P. R. (2007) Emerging nutrient deficiencies in different soil types under rainfed production systems of India. Indian $J$. Fert. 3, 37-46. 
Subbiah, B. and Asija, G. L. (1956) Alkaline permanganate method of available nitrogen determination. Current Sci. 25: 259.

Swarup, A. and Ghosh, A. B. (1980) Changes in the status of water soluble sulphur result of intensive manuring. J. Indian Soc. Soil Sci. 28: 92-98.

Thomas, G., Dalal, R. C. and Standley, J. (2007) No-till effects on organic matter, $\mathrm{pH}$, cation exchange capacity and nutrient distribution in a Luvisol in the semi-arid subtropics. Soil and Tillage Research 94, 295-304.

Uwah, D. F. and Iwo, G. A. (2011) Effectiveness of organic mulches on productivity of maize (Zia maize L.) and weed Growth. J. Anim. Pl. Sci. 21, $525-530$.

Zhang, S. X., Wang, X. B., Jin, K., (2001) Effect of different $\mathrm{N}$ and $\mathrm{P}$ levels on availability of zinc, copper, manganese and iron under arid conditions. Plant Nutr. Fert. Sci. 7, 391-396.

\section{How to cite this article:}

Shankar Ram, A.K. Ghosh, A.K. Nema, Shishu Pal Singh, Vimal Kumar and Preeti Singh. 2018. Influence of Long Term Tillage, Organic and Inorganic Fertilization on Primary Nutrient and $\mathrm{S}$ in Rice - Lentil Cropping Sequence under Dry Land Ecosystem. Int.J.Curr.Microbiol.App.Sci. 7(04): 2511-2522. doi: https://doi.org/10.20546/ijcmas.2018.704.287 